RASĀYAN J. Chem.

Vol. 13 | No. 4 |2215-2222| October - December | 2020 ISSN: 0974-1496 | e-ISSN: 0976-0083 | CODEN: RJCABP

RJC

http://www.rasayanjournal.com

http://www.rasayanjournal.co.in

\title{
EVALUATION OF ANTIBACTERIAL AND ANTIOXIDANT ACTIVITIES OF XANTHONE ISOLATED FROM Orophea corymbosa LEAF
}

\author{
H. P. C. A. Cane ${ }^{1}$, N. Saidi ${ }^{2}$, M. Mustanir ${ }^{2}$, D. Darusman ${ }^{3}$, R. Idroes ${ }^{2,4}$ \\ and M. Musman ${ }^{5, *}$ \\ ${ }^{1}$ Graduate School of Mathematics and Applied Sciences, Graduate Program/Universitas Syiah \\ Kuala, Banda Aceh-23111, (Aceh) Indonesia \\ ${ }^{2}$ Department of Chemistry, Faculty of Mathematics and Natural Science/Universitas Syiah \\ Kuala, Banda Aceh-23111, (Aceh) Indonesia \\ ${ }^{3}$ Department of Soil Science, Faculty of Agriculture/Universitas Syiah Kuala, Banda Aceh- \\ 23111, (Aceh) Indonesia \\ ${ }^{4}$ Department of Pharmacy, Faculty of Mathematics and Natural Science/Universitas Syiah Kuala, \\ Banda Aceh-23111, (Aceh) Indonesia \\ ${ }^{5}$ Department of Chemistry Education, Faculty of Education and Teacher Training/Universitas \\ Syiah Kuala, Banda Aceh-23111, (Aceh) Indonesia \\ *E-mail: musrimusman@unsyiah.ac.id
}

\begin{abstract}
The pharmacological properties (antibacterial and antioxidant) of the ethyl acetate extract from the leaves of Orophea corymbosa Blume Miq. the plant was evaluated and continued for obtaining bioactive compounds through the isolation process. A pure isolate from ethyl acetate extract was analyzed of structure compound using NMR Spectra, FTIR, UV-Vis, and MS (GCMS). An isolated compound was considered to be xanthone derived compound, namely 1hydroxy-2,3-dimethoxyxanthone. Its activities against Gram-negative and positive bacteria were examined with bioindicator Escherichia coli ATCC 25922 and Staphylococcus aureus ATCC 25923, respectively, where the results were then compared to cephazolin; and antioxidant activity with indicator free radical 2,2-diphenyl-1-picrylhydrazyl (DPPH) compared to ascorbic acid. The xanthone compound has good activity as antibacterial and antioxidant. The plant has administrated the potential for handling bacteria and free radicals in this study.

Keywords: Annonaceae, Antibacterial, Antioxidant, Escherichia coli, Staphylococcus aureus, Xanthone.
\end{abstract}

(C) RASĀYAN. All rights reserved

\section{INTRODUCTION}

The application of natural products as medical objects is still in high demand. The natural product is a favorable choice with fewer side effects, safer, ${ }^{1}$ easy to find, and green chemistry. ${ }^{2}$ The discovery of natural products, especially in a tropical and subtropical country, can be simply found in plants. The plants were widely reported to have medicinal property from their metabolites, ${ }^{3}$ which are produced by plant ${ }^{4}$ or endophytic bacteria ${ }^{5}$ as self-defense against pathogens. ${ }^{6,7}$ The metabolites have a lot of medical activities as an antibacterial, ${ }^{8}$ antioxidant, ${ }^{9}$ antimicrobial, ${ }^{10}$ antifungal, ${ }^{11}$ wound healing, ${ }^{12}$ and antibiofilm ${ }^{13}$ agents. The use of plant parts such as a leaf, ${ }^{14}$ roots, ${ }^{15}$ and even fruit ${ }^{16}$ has been traditionally done by indigenous peoples since long time ago. Furthermore, to obtain the metabolite can be simply done by extraction ${ }^{17}$.

The Annonaceae family is widespread in diverse habitats (forests, shrubs and grasslands) in both tropical and subtropical areas and is abundant in rainforest areas around the world. ${ }^{18}$ Many genera from the family were found to have medicinal properties against ulcers, fever, infection, abdominal pains, bronchitis, asthma and wounds. ${ }^{19}$ Moreover, they also have pharmacological activities like antifungal, antibacterial, antimalarial, antioxidant and anticancer agents. ${ }^{20,21}$ Bioactive compounds from plants (i.e xanthone) play an important role in terms of medicine. ${ }^{22,23}$ Xanthone compounds are compounds with a three-ring Rasayan J. Chem., 13(4), 2215-2222(2020) http://dx.doi.org/10.31788/ RJC.2020.1345818

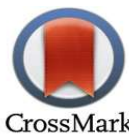


RASĀYAN J. Chem.

Vol. 13 | No. 4 |2215-2222| October - December | 2020

framework (two aromatic rings and one heterocyclic ring) (Fig.-1), which can contain different substituent groups. ${ }^{24}$ Pharmacological activities of xanthones are widely reported, including antioxidant and antimicrobial activities. ${ }^{25}$ Several plant species of this family have been successfully isolated to obtain xanthone compounds. ${ }^{26-28}$ One of the species of the Annonaceae family, Orophea corymbosa Blume Miq., frequently find in the Gayo Lues area. ${ }^{29}$ The leaves of the plant have been commonly used to cure dysentery, type 2 diabetes, fever, nausea, vomiting and vertigo by the local people from generation to generation. It isn't reported on the study on the isolation of the compounds as raw material for medicines. So far, simply publications of extract activity were found via internet searching that labeled the plant has properties of antimicrobial, ${ }^{30}$ muscarinic receptors,${ }^{31}$ lipoxygenase inhibiting, ${ }^{32}$ antiplasmodial, ${ }^{33}$ and antioxidant ${ }^{34}$ For this reason, the objective of this work is to study the antibacterial and antioxidant activities of the xanthone compound isolated from $O$. corymbosa leaves.<smiles>O=c1c2ccccc2oc2ccccc12</smiles>

Fig.-1: Skeleton of Xanthone Compound ${ }^{24}$

\section{Material and Instrumentation}

\section{EXPERIMENTAL}

Leaves of $O$. corymbosa were collected from Gayo Lues District ( $3^{\circ} 53^{\prime} 47,556^{\prime \prime} \mathrm{N}$ 97 25'43,526” E), Aceh Province, Indonesia. The sample was determined by the Research Center for Biology at the Indonesian Institute of Sciences (LIPI), Bogor, Indonesia. Its voucher for the specimen was stored under code $13 /$ Jerig. It is also known as kayu Kijang ${ }^{35}$ by Indonesian.

Materials were $n$-hexane $96 \%$, ethyl acetate $96 \%$, methanol $96 \%$, deuterated chloroform $\left(\mathrm{CDCl}_{3}\right)$, silica gel G 60, TLC plate preparative (silica gel $60 \mathrm{~F}_{254}$ ), free radical 2,2-diphenyl-1-picrylhydrazyl (DPPH), bacteria of Escherichia coli ATCC 25922 and Staphylococcus aureus ATCC 25923, methanol 99.9\%, dimethylsulfoxide (DMSO) 99.9\%, ascorbic acid 99.7\%, reagen $\mathrm{FeCl}_{3}$, aquadest, $\mathrm{NaCl} 0.85 \%, 30 \mu \mathrm{g}$ cephazolin (disc diameter of $6 \mathrm{~mm}$ ), Muller Hinton Agar (MHA), Lactose Broth (LB), paper disc (disc diameter of $6 \mathrm{~mm}$ ), and Whatman filter paper grade 41.

Experiments were carried out with a rotary evaporator, shaker, spectrophotometer, ultraviolet lamp, NMR, incubator, FTIR, GCMS, UV-Vis, and autoclave instruments.

\section{Extraction Plant}

The dried leaves of $O$. corymbosa were mashed and weighed as much as $1.5 \mathrm{~kg}$. It was extracted in stages by maceration technique using either of $n$-hexane $96 \%$, ethyl acetate $96 \%$, and methanol $96 \%$ solvents (3 $\times 2.5 \mathrm{~L}$ ). The filtrates were evaporated to yield of $34.6 \mathrm{~g}$ of $n$-hexane, $68.2 \mathrm{~g}$ of ethyl acetate, and $151.4 \mathrm{~g}$ of methanol extracts, respectively.

\section{Isolation and Elucidation of Compound}

As much as 30 grams ethyl acetate extract was further processed with compound isolation procedure using column chromatography (diameter of column $=5 \mathrm{~cm}$ ) with 400 grams of silica gel G 60 as stationary phase and $n$-hexane: ethyl acetate as mobile phase. The polarity of the mobile phase in the chromatography column process was increased until $n$-hexane: ethyl acetate $(5: 5, \mathrm{v} / \mathrm{v})$. Furthermore, the pure isolate was obtained after the purification using re-chromatography, preparative TLC, and recrystallization. The characterization of the pure isolate was carried out with ${ }^{1} \mathrm{H}, 500 \mathrm{MHz}$, and ${ }^{13} \mathrm{C}, 125 \mathrm{MHz}$ of $1 \mathrm{D}-\mathrm{NMR}$; HSQC, and HMBC of 2D-NMR; GCMS; UV-Vis; as well as FTIR spectrophotometers, which was identified as a xanthone compound (Fig.-2).

\section{Antioxidant Assay}

The antioxidant assay was carried out by scavenging DPPH method..$^{36} \mathrm{~A}$ xanthone compound and positive control (ascorbic acid) were formulated at 5 various concentrations, ranging from 2 to $10(\mu \mathrm{g} / \mathrm{mL})$, in methanol solvent $99.9 \%$, respectively. DPPH solution $(0.1 \mathrm{mM})$ as much as $11 \mathrm{~mL}$ was prepared in 
RASĀYAN J. Chem.

Vol. 13 | No. 4 |2215-2222| October - December | 2020

methanol solvent $99.9 \%$. A $1 \mathrm{~mL}$ solution of DPPH $0.1 \mathrm{mM}$ was dropped in $3 \mathrm{~mL}$ of varying concentrations the xanthone compound and the positive control, respectively. A solution of DPPH $0.1 \mathrm{mM}(1 \mathrm{~mL})$ was dropped in methanol solvent $99.9 \%(3 \mathrm{~mL})$ as a negative control and $4 \mathrm{~mL}$ of methanol solvent $99,9 \%$ as a blank. All various concentrations, respectively after incubation for half an hour in a dark room at room temperature was read absorbance by a spectrophotometer at $517 \mathrm{~nm} .{ }^{37}$ The ability to scavenge the DPPH radical was counted by the formula: \% Inhibition $=\left[(\right.$ Ao-A) $/$ Ao $] \times 100 .{ }^{38}$ Note, Ao (absorbance of negative control), A (absorbance of a xanthone compound and positive control of varying concentrations).

\section{Antibacterial Assay}

Each bacterial strain was inoculated using the subcultures method. ${ }^{39}$ The bacterial suspension was taken from LB liquid media stock ( 0.26 gram dissolved into $20 \mathrm{~mL}$ aquadest) as much as $1 \mathrm{~mL}$ for each bacterium (E. coli and $S$. aureus) and added to respective LB medium ( 0.39 gram dissolved in $30 \mathrm{~mL}$ aquadest). The bacterial suspension in LB media has been shaken for a night at $37^{\circ} \mathrm{C}$ to get fresh bacteria. An $0.85 \%$ (10 $\mathrm{mL}) \mathrm{NaCl}$ solution were prepared to suspend fresh bacteria and the absorbance was measured with a spectrophotometer at $\mathrm{OD}_{600}$ to obtain a value of 0.5-0.8 (to get $10^{8} \mathrm{CFU} / \mathrm{mL}$ ). ${ }^{40}$

The assay of antibacterial was through by disc diffusion on agar media method. ${ }^{41} \mathrm{~A}$ sterile solution of MHA $20 \mathrm{~mL}$ was spilled into a glass petri dish with size $100 \times 15 \mathrm{~mm}$ and allowed to harden. In the next step, both fresh bacteria (E. coli and $S$. aureus) respectively, were spread on agar media in a glass petri dish. Paper discs have the substance of various concentrations of xanthone compound at 30,60 , and $120(\mu \mathrm{g} / \mathrm{mL})$; negative control discs have content of DMSO solvent; and positive control discs (cephazolin) were arranged for media overgrown with bacteria. The incubation of bacteria at $37^{\circ} \mathrm{C}$ has taken 24 hours. Antibacterial test results are the inhibition zone that has been measured in milliliters ( $\mathrm{mm}$ ) using a ruler.

\section{Statistical Analysis}

A simple analytical software (Microsoft Excel 2010) was employed to analyze the results from the antioxidant and antibacterial assay. The data were provided in terms of mean and standard deviation (mean \pm standard deviation). For representing the result of the concentration variation $(\mu \mathrm{g} / \mathrm{mL})$ on the inhibition (\%), linear regression on the antioxidant test has been utilized to calculate the $\mathrm{IC}_{50}$ value.

\section{Structural Elucidation}

\section{RESULTS AND DISCUSSION}

A pure isolate has been elucidated by UV, IR, MS and NMR spectroscopy and indicated the xanthones compound skeleton. ${ }^{24}$ Based on structural elucidation, the pure isolate compound isolated in the $O$. corymbosa plant was the same as the 1-hydroxy-2,3-dimethoxyxanthone compound (Fig.-2) isolated from the Polygala arillata plant. ${ }^{42}$ However, 1-hydroxy-2,3-dimethoxyxanthone compound is a compound that has been found for the first time in the $O$. corymbosa plant. In the previous report, the structural elucidation of a known compound of 1-hydroxy-2,3-dimethoxyxanthone using NMR was limited only to the $1 \mathrm{H}$ $\mathrm{NMR}^{42}$. Therefore, this study displays the results of the elucidation with additional parameters of NMR, namely ${ }^{13} \mathrm{C}-\mathrm{NMR}$, HSQC, and HMBC.<smiles>COc1cc2oc3ccccc3c(=O)c2c(O)c1OC</smiles>

Fig.-2: The Compound of 1-Hydroxy-2,3-dimethoxyxanthone

The pure isolate has characteristic yellowish needles, m.p $215-218{ }^{\circ} \mathrm{C}$, and UV spectra have shown $\lambda_{\max }=$ 201.8, 365 and 383 (in methanol). The spectrum of IR ( $\mathrm{KBr}$ ) has detected the attendance of a carbonyl group $\mathrm{C}=\mathrm{O}\left(1697 \mathrm{~cm}^{-1}\right)$, hydroxy group -OH $\left(3487 \mathrm{~cm}^{-1}\right)$ and aromatic ring $\mathrm{C}$-benzene $\left(900-650 \mathrm{~cm}^{-1}\right)$. The GCMS data have given $\mathrm{m} / \mathrm{z}, 272,257,210,181,153$ and 111 . 
RASĀYAN J. Chem.

Vol. 13 | No. 4 |2215-2222| October - December | 2020

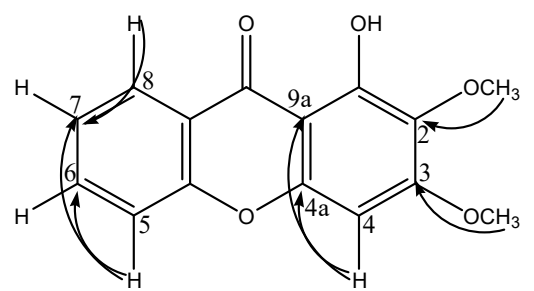

Fig.-3: The Correlation HMBC of 1-Hydroxy-2,3-dimethoxyxanthone

Table-1: ${ }^{1} \mathrm{H}-\mathrm{NMR}$ and ${ }^{13} \mathrm{C}-\mathrm{NMR}$ Spectra of Pure Isolate and Reference ${ }^{42}$ of 1-Hydroxy-2,3-dimethoxyxanthone Compound

\begin{tabular}{|c|c|c|c|c|}
\hline \multirow[b]{2}{*}{ Position } & \multicolumn{2}{|c|}{ Pure Isolate } & \multicolumn{2}{|c|}{ 1-hydroxy-2,3-dimethoxyxanthone ${ }^{42}$} \\
\hline & $\begin{array}{c}\delta \mathrm{H}(\mathrm{ppm}) \\
\left(\mathrm{CDCl}_{3}, 500 \mathrm{MHz}\right)\end{array}$ & $\begin{array}{c}\delta \mathrm{C}(\mathrm{ppm}) \\
\left(\mathrm{CDCl}_{3}, 125 \mathrm{MHz}\right)\end{array}$ & $\begin{array}{c}\delta \mathrm{H}(\mathrm{ppm}) \\
\left(\mathrm{CDCl}_{3}, 60 \mathrm{MHz}\right)\end{array}$ & $\delta \mathrm{C}(\mathrm{ppm})$ \\
\hline 1 & $8.10(1 \mathrm{H}, \mathrm{s}, \mathrm{OH})$ & 142.46 & $12.74(1 \mathrm{H}, \mathrm{s}, \mathrm{OH})$ & - \\
\hline 2 & - & 149.29 & - & - \\
\hline 3 & - & 147.42 & - & - \\
\hline 4 & $7.14(1 \mathrm{H}, \mathrm{s})$ & 105.22 & $6.72(1 \mathrm{H}, \mathrm{s})$ & - \\
\hline $4 \mathrm{a}$ & - & 135.35 & - & - \\
\hline 5 & $9.21(1 \mathrm{H}, \mathrm{m})$ & 126.75 & $8.28(1 \mathrm{H}, \mathrm{m})$ & - \\
\hline 6 & $7.54(1 \mathrm{H}, \mathrm{m})$ & 125.18 & $7.70-7.20(1 \mathrm{H}, \mathrm{m})$ & - \\
\hline 7 & $7.55(1 \mathrm{H}, \mathrm{m})$ & 126.70 & $7.70-7.20(1 \mathrm{H}, \mathrm{m})$ & - \\
\hline 8 & $7.82(1 \mathrm{H}, \mathrm{m})$ & 128.80 & $7.70-7.20(1 \mathrm{H}, \mathrm{m})$ & - \\
\hline $8 \mathrm{a}$ & - & 116.63 & - & - \\
\hline 9 & - & 167.11 & - & - \\
\hline $9 \mathrm{a}$ & - & 122.78 & - & - \\
\hline $10 \mathrm{a}$ & - & 133.60 & - & - \\
\hline $\mathrm{OCH}_{3}-2$ & $4.16(3 \mathrm{H}, \mathrm{s})$ & 60.34 & $3.95(\mathrm{~s})$ & - \\
\hline $\mathrm{OCH}_{3}-3$ & $4.61(3 \mathrm{H}, \mathrm{s})$ & 63.47 & $4.02(\mathrm{~s})$ & - \\
\hline
\end{tabular}

As presented in Table-1, the ${ }^{1} \mathrm{H}$ NMR spectrum indicated the detected 12 protons. Two methoxy protons as singlet signals were detected with $\delta_{\mathrm{H}} 4.16 \mathrm{ppm}$ for $\mathrm{OCH}_{3}-2$ and $\delta_{\mathrm{H}} 4.61 \mathrm{ppm}$ for $\mathrm{OCH}_{3}-3$. Five signals of aromatic protons consisted of one singlet signal with a $\delta_{\mathrm{H}} 7.14 \mathrm{ppm}(\mathrm{s}, 1 \mathrm{H}, \mathrm{H}-4)$. Four multiplet aromatic protons were $\delta_{\mathrm{H}} 9.21 \mathrm{ppm}(\mathrm{m}, 1 \mathrm{H}, \mathrm{H}-5), \delta_{\mathrm{H}} 7.54 \mathrm{ppm}(\mathrm{m}, 1 \mathrm{H}, \mathrm{H}-6), \delta_{\mathrm{H}} 7.55 \mathrm{ppm}(\mathrm{m}, 1 \mathrm{H}, \mathrm{H}-7)$ and $\delta_{\mathrm{H}} 7.82$ $\operatorname{ppm}(\mathrm{m}, 1 \mathrm{H}, \mathrm{H}-8)$. One hydroxy $(\mathrm{OH})$ group was identified at $\delta_{\mathrm{H}} 8.10 \mathrm{ppm}$ as a singlet signal.

The ${ }^{13} \mathrm{C}$ NMR spectrum (Table-1) had shown signals from 15 carbon atoms consisting of 5 aromatic carbons, 4 substituted aromatic carbons, 2 methylated phenolic carbons, 1 phenolic carbon, 2 methoxy carbons, and 1 carbonyl carbon with chemical shifts $\left(\delta_{\mathrm{C}}, \mathrm{ppm}\right)$, respectively C-4 $(105.22), \mathrm{C}-5$ (126, 75), C-6 (125.18), C-7 (126.70), C-8 (128.80) were aromatic carbon; C-4a (135.35), C-8a (116.63), C-9a (122.78), C-10a (133.60) were substituted aromatic carbons; C-2 (149.29), C-3 (147.42) were methylated phenolic carbons; $\mathrm{C}-1$ (142.46) was phenolic carbon; $\mathrm{OCH}_{3}-2(60,34), \mathrm{OCH}_{3}-3(63,47)$ were methoxy carbon and C-9 $(167,11)$ was carbonyl carbon.

The elucidation of the structure with ${ }^{1} \mathrm{H}-\mathrm{NMR}$ and ${ }^{13} \mathrm{C}-\mathrm{NMR}$ can be clarified by 2D-NMR (HSQC, and HMBC). The HSQC spectrum has shown that the proton of methoxy at $\delta_{H} 4.16$ ppm correlates with carbon at $\delta_{\mathrm{C}} 60.34 \mathrm{ppm}$ and the methoxy proton at $\delta_{\mathrm{H}} 4.61 \mathrm{ppm}$ correlates with carbon at $\delta_{\mathrm{C}} 63.47 \mathrm{ppm}$. Furthermore, the signals from the 5 protons that appear to correlate with aromatic carbon. The HMBC spectrum shows a correlation between proton and carbon (see Fig.-3). The proton of the methoxy group, namely $\mathrm{OCH}_{3}-2\left(\delta_{\mathrm{H}} 4.16 \mathrm{ppm}, \mathrm{s}, 3 \mathrm{H}\right)$ and $\mathrm{OCH}_{3}-3\left(\delta_{\mathrm{H}} 4.61 \mathrm{ppm}, \mathrm{s}, 3 \mathrm{H}\right)$, correlated respectively to aromatic carbon at $\mathrm{C} 2\left(\delta_{\mathrm{C}} 149.29 \mathrm{ppm}\right)$ and $\mathrm{C} 3\left(\delta_{\mathrm{C}} 147.42 \mathrm{ppm}\right)$. A correlation also appeared from $\mathrm{H}-4\left(\delta_{\mathrm{H}} 7.14 \mathrm{ppm}\right.$, $\mathrm{s}, 1 \mathrm{H})$ to $\mathrm{C}-4 \mathrm{a}\left(\delta_{\mathrm{C}} 135.35\right), \mathrm{C}-9 \mathrm{a}\left(\delta_{\mathrm{C}} 122.78\right)$; H-5 ( $\left.\delta_{\mathrm{H}} 9.21 \mathrm{ppm}, \mathrm{m}, 1 \mathrm{H}\right)$ to C-6 ( $\left.\delta_{\mathrm{C}} 125.18\right), \mathrm{C}-7$ (126.70); and $\mathrm{H}-8\left(\delta_{\mathrm{H}} 7.82 \mathrm{ppm}, \mathrm{m}, 1 \mathrm{H}\right)$ to $\mathrm{C}-7\left(\delta_{\mathrm{C}} 126.70\right)$.

GCMS data of this compound produced $\mathrm{m} / \mathrm{z} 272$. Its $\mathrm{MS}^{2}$ fragmentation produced two peaks at $\mathrm{m} / \mathrm{z} 257$ (loss of $\mathrm{CH}_{3}$ ) and 210 (loss of two $\mathrm{OCH}_{3}$ ), respectively. The precursor of ion $\mathrm{MS}^{2} \mathrm{~m} / \mathrm{z} 210$ obtained MS at $\mathrm{m} / \mathrm{z} 181$ and 193 suggested lost the $\mathrm{COH}$ and $\mathrm{OH}$, respectively. The precursor at $\mathrm{MS}^{3} \mathrm{~m} / \mathrm{z} 181$ yielded in 
RASĀYAN J. Chem.

Vol. 13 | No. 4 |2215-2222| October - December | 2020

fragmentation of $\mathrm{MS}^{4}$ with a value of $\mathrm{m} / \mathrm{z} 153$ (lost CO). The precursor of the ion at $\mathrm{MS}^{3} \mathrm{~m} / \mathrm{z} 193$ resulted in $\mathrm{MS}^{4} \mathrm{~m} / \mathrm{z} 111$ (lost $\mathrm{COH}, \mathrm{CO}$, and $\mathrm{C}_{2} \mathrm{H}$ ). The possible fragmentation patterns that occur from the compound are described in Fig.-4.

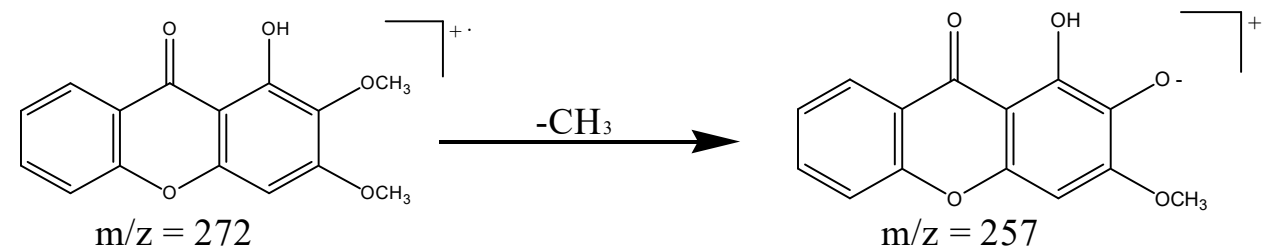<smiles></smiles>
$\mathrm{m} / \mathrm{z}=210$<smiles>CCCCC(C)C(=O)O</smiles>

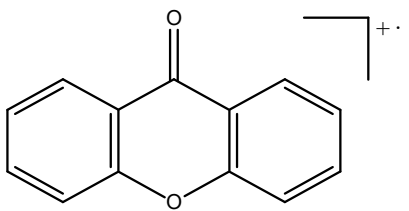

$\mathrm{m} / \mathrm{z}=193$<smiles>CCCC(=O)c1c(O)cccc1-c1ccccc1</smiles>

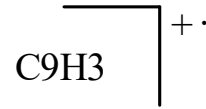

$\mathrm{m} / \mathrm{z}=111$

$\mathrm{m} / \mathrm{z}=153$

Fig.-4: The Prediction of Fragmentation Patterns of 1-Hydroxy-2,3-dimethoxyxanthone

\section{Antioxidant Activity}

The strength of antioxidant activity was categorized in Table-2. The antioxidant activity came from the performance of its secondary metabolites, mainly from the flavonoid, alkaloid, phenol, and saponin substances. The substances worked to scavenge the free radical of DPPH by reducing DPPH to 1,1diphenyl-2-picrylhydrazine compound. The qualitative observation confirmed that the DPPH solution color switched from purple to yellow. The intensity of the color change showed the potential for free radical capture by antioxidant agent. ${ }^{45}$

Table-2: Category of Strong Antioxidant and Antimicrobial Activities

\begin{tabular}{c|c|c}
\hline Activity & Strength Category & \multirow{2}{*}{ Ref. } \\
\hline Antioxidant & $<100 \mu \mathrm{g} / \mathrm{mL}$ (strong) & \multirow{2}{*}{43} \\
\cline { 2 - 2 } & $101-150 \mu \mathrm{g} / \mathrm{mL}$ (moderate) & \multirow{2}{*}{} \\
\cline { 2 - 2 } & $151-200 \mu \mathrm{g} / \mathrm{mL}$ (weaker) & \multirow{2}{*}{4} \\
\hline Antimicrobial & $\geq 20 \mathrm{~mm}$ (strong) & \\
\cline { 2 - 2 } & $12 \mathrm{~mm}-20 \mathrm{~mm}$ (moderate) & \\
\cline { 2 - 2 } & $\leq 12 \mathrm{~mm}$ (weak) & \\
\hline
\end{tabular}


RASĀYAN J. Chem.

Vol. 13 | No. 4 |2215-2222| October - December | 2020

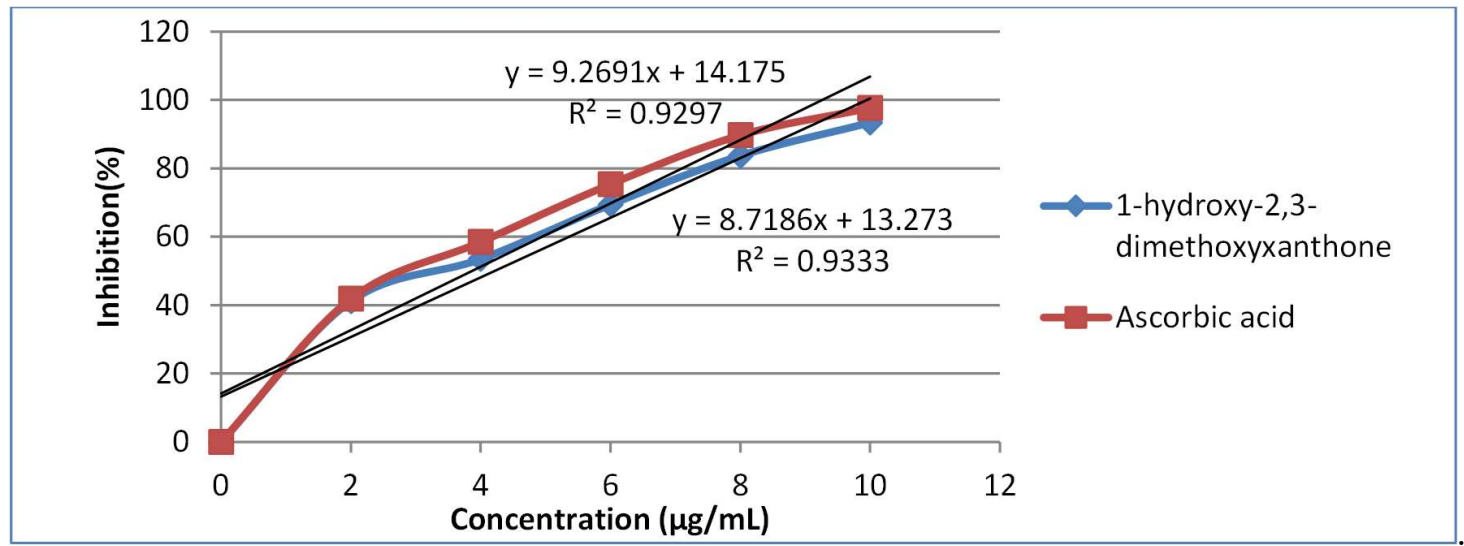

Fig.-5: Graph of Linear Regression Analysis of the Results of the Concentration Variation $(\mu \mathrm{g} / \mathrm{mL})$ on the Inhibition (\%) of 1-Hydroxy-2,3-dimethoxyxanthone

The antioxidant activity of xanthone compound can be determined by $\mathrm{IC}_{50}$ value. Linear regression analysis of the results of the concentration variation $(\mu \mathrm{g} / \mathrm{mL})$ on the inhibition $(\%)$ was used to calculate the $\mathrm{IC}_{50}$ value in the antioxidant test (Fig.-5). The xanthone compound had shown very strong antioxidant properties with the resulted of an $\mathrm{IC}_{50}$ value of $4.21 \mu \mathrm{g} / \mathrm{mL}$. Many reports of xanthone compounds have antioxidant activity. ${ }^{46}$ In this study, for the first time the antioxidant property of 1-hydroxy-2,3-dimethoxyxanthone was reported.

\section{Antibacterial Activity}

The strength classification of antimicrobial activity based on the inhibition zone values has categorized in Table-2. The antibacterial action of the secondary metabolites could be assumed in several ways viz. Disturbing the function and structure of membranes, interfering with the synthesis/function of DNA/RNA, and inhibiting cell wall synthesis or protein. ${ }^{47,48}$

The xanthone compound indicated moderate activities against both used bacteria with an average inhibition zone value ranged (mean $\pm \mathrm{SD}$ ) from $14.34 \pm 0.65 \mathrm{~mm}$ to $19.33 \pm 0,58 \mathrm{~mm}$ (E. coli) and $11.98 \pm 0.02 \mathrm{~mm}$ to $14.95 \pm 0.09 \mathrm{~mm}(S$. aureus $)$ respectively, for concentrations ranging 30 to $120(\mu \mathrm{g} / \mathrm{mL})$. Many reports that the xanthone compounds have antibacterial activity. ${ }^{49}$ However, the 1-hydroxy-2,3dimethoxyxanthone compound was first tested for antibacterial.

\section{CONCLUSION}

The xanthone compound (1-hydroxy-2,3-dimethoxyxanthone) was successfully afforded from the isolation of ethyl acetate extract of $O$. corymbosa. The xanthone has very strong antioxidant and moderate antibacterial activities. Hence, the $O$. corymbosa plant could be verified as a source of medicinal raw materials to administrate the bacteria and free radicals.

\section{ACKNOWLEDGEMENT}

The research was funded by KEMENRISTEKDIKTI through the "PMDSU" scheme. Therefore, the authors would like to acknowledge KEMENRISTEKDIKTI for financially supporting this research.

\section{REFERENCES}

1. K. Swarnalatha, C.H.V.K. Babu and B.H. Babu, Rasayan Journal of Chemistry, 12, 907 (2019), DOI: 10.31788/RJC.2019.1225168

2. M. Paristiowati, M. Moersilah, M.M. Stephanie, Z. Zulmanelis, R. Idroes and R.A. Puspita, In Journal of Physics: Conference Series, Bali, Indonesia, pp. 1-6 (2019), DOI:10.1088/17426596/1402/5/055041

3. D.S. Ningsih, R. Idroes, B.M. Bachtiar and Khairan, In IOP Conference Series Materials Science and Engineering, Aceh, Indonesia, pp. 1-8 (2019), DOI:10.1088/1757-899X/523/1/012009

4. C. Nuraskin, Marlina, R. Idroes, C. Soraya and Djufri, Rasayan Journal of Chemistry, 13, 18 (2020), DOI:10.31788/RJC.2020.1315434 
RASĀYAN J. Chem.

Vol. 13 | No. 4 |2215-2222| October - December | 2020

5. Zulfendi, R. Idroes and Khairan, In IOP Conference Series Materials Science and Engineering, Aceh, Indonesia, pp. 1-8 (2019), DOI:10.1088/1757-899X/523/1/012013

6. P.K. Mukherjee, B.A. Horwitz and C.M. Kenerley, Microbiology, 158, 35(2012), DOI:10.1099/mic.0.053629-0

7. V.N. Ariharan, V.N.M. Devi and P.N. Prasad, Rasayan Journal of Chemistry, 6, 134(2013).

8. R. Rahmad, N. Earlia, C. Nabila, I. Inayati, M. Amin, C.R.S. Prakoeswa, K. Khairan and R. Idroes, In IOP Conference Series Materials Science and Engineering, Aceh, Indonesia, pp. 1-6 (2019), DOI:10.1088/1757-899X/523/1/012011

9. E. Suhartono, B. Setiawan, P.B. Santosa, R. Idroes and M.S. Indrawan, In Journal of Physics: Conference Series, Malang, Indonesia, pp.1-4 (2019), DOI:10.1088/1742-6596/1374/1/012057

10. A. Mathur, R. Bhat, G.B.K.S. Prasad, V.K. Dua, S.K. Verma and P.K. Agarwal, Rasayan Journal of Chemistry, 3, 615(2010).

11. O. Cortés-Zavaleta, A. López-Malo, A. Hernández-Mendoza and H. S. García, International Journal of Food Microbiology, 173, 30(2014), DOI:10.1016/j.ijfoodmicro.2013.12.016

12. N. Earlia, R. Rahmad, M. Amin, C. Prakoeswa, K. Khairan and R. Idroes, Sains Malaysiana, 48, 1019(2019), DOI:10.17576/jsm-2019-4805-10

13. S. Hnamte, P. Subhaswaraj, S.K. Ranganathan, D.R. Ampasala, G. muralitharan and B. Siddhardha, Journal of Microbiology, Biotechnology and Food Sciences, 8, 1135(2019), DOI:10.15414/jmbfs.2019.8.5.1135-1140

14. C.A. Nuraskin, Marlina, R. Idroes, C. Soraya and Djufri, In IOP Conference Series Materials Science and Engineering, Aceh, Indonesia, pp. 1-6 (2019), DOI:10.1088/1757-899X/523/1/012008

15. P.T. Motsumi, T. Qwebani-Ogunleye, I.P. Ejidike, F.M. Mtunji and Z. Nate, Rasayan Journal of Chemistry, 13, 423(2020), DOI: 10.31788/RJC.2020.1315594

16. T.E. Tallei, J.J. Pelealu, H.N. Pollo, G.A.V. Pollo, A.A. Adam, Y. Effendi, A. Karuniawan, S. Rahimah and R. Idroes, Data in Brief, 27, 1(2019), DOI:10.1016/j.dib.2019.104681

17. N. Earlia, Muslem, R. Suhendra, M. Amin, C.R.S. Prakoeswa, Khairan and R. Idroes, The Scientific World Journal, 2019, 1(2019), DOI:10.1155/2019/8605743

18. J.G. Dolab, B. Lima, E. Spaczynska, J. Kos, N.H. Cano, G. Feresin, A. Tapia, F. Garibotto, E. Petenatti, M. Olivella, R. Musiol, J. Jampilek and R.D Enriz, Molecules, 23, 1(2018), DOI: $10.3390 /$ molecules 23051187

19. A. Attiq, J. Jalil and K. Husain, Frontiers in Pharmacology, 8, 1(2017), DOI:10.3389/fphar.2017.00752

20. N. Aminimoghadamfarouj, A. Nematollahi and C. Wiart, Journal of Asian Natural Products Research, 13, 465(2011), DOI:10.1080/10286020.2011.570265

21. N. Tsabang, P.V.T. Fokou, L.R.Y. Tchokouaha, B. Noguem, I. Bakarnga-Via, M.S.D. Nguepi, B.A. Nkongmeneck and F.F. Boyom, Journal of Ethnopharmacology, 139, 171(2012), DOI:10.1016/j.jep.2011.10.035

22. H.R. El-Seedi, M.A. El-Barbary, D.M.H. El-Ghorab, L. Bohlin, A.-K. Borg-Karlson, U. Goransson and R. Verpoorte, Current Medicinal Chemistry, 17, 854 (2010), DOI: 10.2174/092986710790712147

23. A.J. Teodoro, Oxidative Medicine and Cellular Longevity, 2019, 1(2019), DOI: $10.1155 / 2019 / 3765986$

24. J. Ruan, C. Zheng, Y. Liu, L. Qu, H. Yu, L. Han, Y. Zhang and T. Wang, Molecules, 22, 1(2017), DOI:10.3390/molecules22101698

25. H.R. El-seedi, M.A. Salem, O.M. Khattab, A.A. El-Wahed, D.M. El-Kersh, S.A.M. Khalifa, A. Saeed, M.M. Abdel-Daim, N.H. Hajrah, M.M. Alajlani, M.F. Halabi, A.R. Jassbi, S.G. Musharraf and M.A. Farag, 2020, Dietary xanthone, in: J. Xiao, S.D. Sarker, Y. Asakawa (eds.), Handbook of Dietary Phytochemicals, Springer, Singapore, pp. 1-22, DOI: 10.1007/978-981-13-1745-3_11-1

26. N. Anantachoke, P. Tuchinda, C. Kuhakarn, M. Pohmakotr and V. Reutrakul, Pharmaceutical Biology, 50, 78(2012), DOI: 10.3109/13880209.2011.636176

27. E.V. Costa, F.d.A. Marques, M.L.B. Pinheiro, R.M. Braga, C. Delarmelina, M.C.T. Duarte, A.L.T.G. Ruiz, J.E.d. Carvalho and B.H.L.N.S. Maia, Journal of the Brazilian Chemical Society, 22, 1111(2011), DOI:10.1590/S0103-50532011000600016 
RASĀYAN J. Chem.

Vol. 13 | No. 4 |2215-2222| October - December | 2020

28. C. Sabphon, T. Sermboonpaisarn and P. Sawasdee, Journal of Medicinal Plants Research, 6, 3781(2012), DOI: 10.5897/JMPR12.346

29. I.M. Turner, Gardens' Bulletin Singapore, 70, 409(2018), DOI:10.26492/gbs70(2).2018-11

30. P.Y. Chung, L.Y. Chung, Y.F. Ngeow, S.H. Goh and Z. Imiyabir, Pharmaceutical Biology, 42, 292(2004), DOI: 10.1080/13880200490511837

31. L.Y. Chung, K.F. Yap, M.R. Mustafa, S.H. Goh and Z. Imiyabir, Pharmaceutical Biology, 43, 672(2005), DOI: 10.1080/13880200500383439

32. L.Y. Chung, W.K. Soo, K.Y. Chan, M.R. Mustafa, S.H. Goh and Z. Imiyabir, Pharmaceutical Biology, 47, 1142(2009), DOI: 10.3109/13880200903008724

33. S. Khozirah, A.N. Rain, M.J.S. Najila, Z. Imiyabir, L. Madani, C. Rohaya, M. Rosilawati, H. Nuziah, S.H. Goh and I. Zakiah, Pertanika Journal of Science and Technology, 19, 11(2011).

34. H.P.C.A. Cane, N. Saidi, Mustanir and M. Musman, In Proceedings of The $7^{\text {th }}$ AIC-ICMR on Health and Life Sciences, Banda Aceh, Indonesia, pp. 281-285 (2017).

35. R.H. Mahmudah, E.B. Walujo, W. Wardhana and T. Susanti, In Proceedings National conference of MIPA and Education of MIPA, Jambi, Indonesia, pp. 221-229 (2012). [In Indonesian]

36. D.H.S. Palupi, D.S. Retnoningrum, M.I. Iwo and A.A. Soemardji, Rasayan Journal of Chemistry, 13, 636(2020), DOI: 10.31788/RJC.2020.1315519

37. B. Ginting, L. Marpaung, T. Barus and P. Simanjuntak, Asian Journal of Chemistry, 28, 199(2016), DOI:10.14233/ajchem.2016.19342

38. L. Jing, H. Ma, P. Fan, R. Gao and Z. Jia, BMC Complementary and Alternative Medicine, 15, 1(2015), DOI:10.1186/s12906-015-0820-3

39. R. Btissam, E.M. Fatima, E. Kamal, G. Hassane and N. Mohamed, Pharmacognosy Journal, 10, 81 (2018), DOI:10.5530/pj.2018.1.16

40. F. Modarresi, O. Azizi, M.R. Shakibaie, M. Motamedifar, E. Mosadegh and S. Mansouri, Virulence, 6, 152 (2015), DOI: 10.1080/21505594.2014.1003001

41. H.P.C.A. Cane, N. Saidi, M. Yahya, D. Darusman, E. Erlidawaty, S. Safrida, M. Musman, The Scientific World Journal, 2020, 1(2020), DOI:10.1155/2020/2983129

42. S. Ghosal, S. Banerjee, R.B.P.S. Chauhan and R.S. Srivastava, Journal of the Chemical Society Perkin Transactions, 1, 740(1977), DOI:10.1039/P19770000740

43. M. Simorangkir, W. Hutabarat, B. Nainggolan, S. Silaban, Rasayan Journal of Chemistry, 12, 959(2019), DOI: 10.31788/RJC.2019.1225095

44. S.M. Marotta, F. Giarratana, A. Parco, D. Neri, G. Ziino, A. Giuffrida and A. Panebianco, Italian Journal of Food Safety, 5, 210(2016), DOI:10.4081/ijfs.2016.6176

45. Supomo, E.S. Syamsul, A. Apriliana, C. Saleh, Erwin and D. Lestari, Rasayan Journal of Chemistry, 12, 1340(2019), DOI: 10.31788/RJC.2019.1235264

46. M.E. Gondokesumo, B. Pardjianto, S.B. Sumitro, W. Widowati and K. Handono, Pharmacognosy Journal, 11, 369(2019), DOI:10.5530/pj.2019.11.56

47. M.M. Cowan, Clinical Microbiology Reviews, 12, 564(1999), DOI:10.1128/CMR.12.4.564

48. N.S. Radulovic, P.D. Blagojevic, Z.Z. Stojanovic-Radic and N.M. Stojanovic, Current Medicinal Chemistry, 20, 932(2013), DOI:10.2174/0929867311320070008

49. I. Miladiyah and F.J. Rachmawaty, Indonesian Journal of Medicine and Health, 8, 124(2017), DOI:10.20885/JKKI.Vol8.Iss2.art8

[RJC-5818/2020] 